\title{
Genesis of an indigenous social-ecological landscape in eastern Panama
}

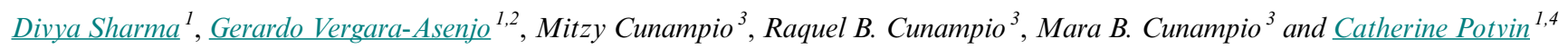

\begin{abstract}
Knowledge of the interplay between ecological and social influences in the context of land-use decision-making is sparse. To help fill this gap, we conducted participatory land-cover mapping in an indigenous territory of eastern Panama to identify factors that influenced household land-use decisions. The map illustrated a mosaic of land cover dominated by pasture. Primary discourse on influences from 35 semistructured interviews with landowners, women, and youth emphasized economic concerns, such as subsistence, and social-cultural factors, such as reticence to abandon traditional agriculture. Multivariate analysis showed that timing of family settlement helped determine proportion of forest cover, and place of origin helped determine proportion of short fallow for agriculture. Cultural norms and economic opportunities inform gendered perspectives; women perceived internal social-cultural influences and men perceived external and ecological influences on the land. Giving consideration to subsistence, traditional land uses, social organization, and women's perspectives could inform future communal reforestation.
\end{abstract}

Key Words: eastern Panama; deforestation; forest cover; indigenous migration; land-cover mapping; land-use change; land-use decisions; livelihood strategies; local knowledge; reforestation; social-ecological landscape

\section{INTRODUCTION}

Over 1 billion extremely poor people around the world, the majority being rural dwellers, rely on forest resources for livelihoods (World Bank 2004). In Central America, where 45\% of the population is rural, deforestation rates are the highest in the world (Food and Agriculture Organization of the United Nations 2010). Land-use decisions in rural Latin America are informed by biogeophysical land characteristics (Nelson et al. 2001, Arroyo-Mora et al. 2005, Ellis et al. 2010), household demographics and socioeconomics (Walker et al. 2000, Perz 2001, Abizaid and Coomes 2004, Carr 2005, Chowdhury and Turner 2006, Mena et al. 2006, Potvin et al. 2006, Tschakert et al. 2007, Gray et al. 2008, Ellis et al. 2010, Sydenstricker-Neto 2012), ethnicity (Carr 2005, Chowdhury and Turner 2006), legal land title (Nelson et al. 2001, Carr 2005), public policies (Arroyo-Mora et al. 2005, Potvin et al. 2006), and market influences (Simmons 1997, Gray et al. 2008; see Pacheco et al. 2011). The labeling of swidden agriculture as the principal cause of tropical deforestation has thus been questioned (Geist and Lambin 2002, Seidenberg et al. 2003, Ickowitz 2006, Makana and Thomas 2006, Sirén 2007, Mertz et al. 2008). Instead, local case studies that consider ecological, social, economic, and political systems are needed to understand the complex interrelationships driving land-use change (Lambin et al. 2001, Lambin et al. 2003, Chazdon et al. 2009, Rudel et al. 2009).

A social-ecological approach to land-use studies enables the consideration of diverse drivers, including historical factors, local perceptions, and gendered perspectives. Recent research recognizes that landscapes are a product of history (Rhemtulla and Mladenoff 2007, Gray et al. 2008, Moran 2010). For example, differential settlement histories between two groups of indigenous Peruvian Asháninka partly explained market integration: the group more involved in the market had arrived later from an area of high colonization (Peralta and Kainer 2008). Venezuelan Barís settlement patterns have influenced the landscape, with sedentarization and market integration leading to deforestation
(Behrens et al. 1994). In the Maya Biosphere Reserve, farmers who had land in their previous settlements were those who practiced more agricultural intensification after migration (Carr 2005).

Land-use change studies must address indigenous resource users' perceptions, which are influenced by their worldviews and inform decision-making (Vanclay 2003, Leonard et al. 2013, Meyfroidt 2013). These include the services forest dwellers perceive to derive from forests (Castillo et al. 2005). In a mangrove deforestation study in Cameroon, for example, lack of flooding and deforestation risk perception meant that mangrove protection would be limited (Munji et al. 2014). Diverse perceptions of causes of deforestation influenced degrees of interest in conservation in Los Tuxtlas, Mexico (Durand and Lazos 2008).

Gender can impact perceived influences on the landscape. Households' livelihood strategies can be determined by gender relations comprising consignment of women's duties to household chores, limited access of females to schooling, and fewer opportunities for women to leave the home or migrate out of the community (Ellis 1998). Distinct livelihoods entail gendered relationships with the environment (Leach et al. 1995); women and men can view the landscape differently depending upon the values they derive from resources, which are determined in part by gendered labor divisions (Etongo and Glover 2012).

Thus, land-use changes result from explicitly linked ecological and social interactions (Redman et al. 2004). To consider diverse influences on land-use decisions and contribute case study data to knowledge on global deforestation, we adopted a socialecological approach to the study of landscape-level land-use change. The objectives of our study were to (1) identify factors that have influenced land-use decisions leading to low forest cover in the indigenous Emberá lands of Piriatí in eastern Panama, and (2) determine the influences of history and gendered perspectives on the landscape following emergence of these factors during data collection.

${ }^{1}$ Department of Biology, McGill University, ${ }^{2}$ Instituto Forestal de Chile, ${ }^{3}$ Community of Piriatí-Emberá, Panama, ${ }^{4}$ Smithsonian Tropical Research Institute 
In Panama, indigenous peoples have practiced traditional shifting cultivation for thousands of years (McKay 1990, as cited in Fischer and Vasseur 2000). The eastern Panamanian landscape was previously old-growth forest or a highly advanced successional stage (Araúz et al. 1973, McKay 1984), but has become mosaics of land uses and secondary forests (Wali 1993, St-Laurent et al. 2013, Vergara-Asenjo et al. 2015). This transition must be understood in the context of historical factors like Emberá migration, Pan-American Highway expansion, hydroelectric dam construction, and small-scale colonist encroachment (Herlihy 1985; Wali 1989, 1993; Horton 2006; StLaurent et al. 2013). Emberá men are traditionally responsible for hunting, physical tasks in agriculture, dealing with outsiders, and handling money, while women take care of the household (Herlihy 1986, Kane 1986, Kane 1994). When men are those making land-use decisions, female perspectives can be excluded, with potential outcomes on the resultant landscape.

Our objective was developed jointly with indigenous community leaders, who highlighted concern over deforestation in their lands and their desire to incorporate reforestation in a land-use management plan. Our participatory approach reflects the call to conduct research that is meaningful for locals and informed by local knowledge (Grove and Burch 1997, Scoones 1999, Smith 2003, Evans et al. 2006, Chazdon et al. 2009).

\section{METHODS}

\section{Study site}

The Piriatí communal lands (tierras colectivas) comprise 3867 ha in the Alto Bayano watershed, $100 \mathrm{~km}$ east of Panama City along the Pan-American Highway (Fig. 1). Piriatí was formed in the early 1970s following relocation of Bayano River inhabitants after hydroelectric dam construction. The watershed has since witnessed an influx of colonists from western provinces searching for land (Herrera 1986, Wali 1989, 1993, St-Laurent et al. 2013). The village has 497 people, 117 families, and 56 landowners who practice swidden agriculture and cattle ranching. The eastern communal lands, Catrigandí, form an area outside the village where Emberá live with Latino farmers (campesinos). The lands are communal, i.e., belonging to everyone while individual landowners manage each parcel, and were legally recognized by the Panamanian government in 2014 (see Wickstrom 2003, Herrera 2012, Runk 2012 for a discussion of land rights struggles).

Fig. 1. Location of the indigenous community of PiriatíEmberá in eastern Panama.

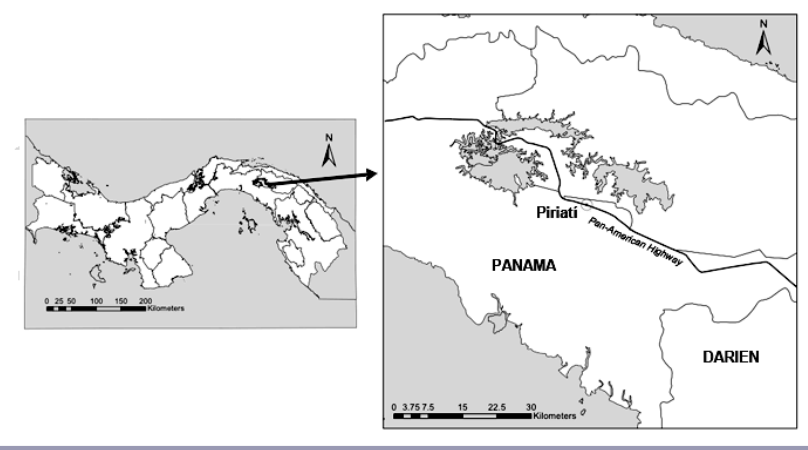

\section{Data collection}

Participatory mapping of community lands

Participatory maps communicate facets of the landscape relevant and important to locals (Smith 2003). In 2012, participatory mapping of land cover in Piriatí was begun following the methods of Potvin et al. (2006). In a workshop, 45 landowners discussed appropriate land cover classes, including secondary forest, tall and short fallow, and pasture. They drew their parcels and associated land cover on a base map derived from 2012 RapidEye ${ }^{\circledR}$ satellite images of the region (Vergara-Asenjo et al. 2015). We validated this map in a participatory manner (see Appendix 1).

\section{Household interviews}

To quantify the relationship of land cover in the plot to household demographic data and factors perceived to influence land-use decisions, we conducted a participatory wealth ranking (see Appendix 1) and 35 semistructured interviews in 2013. Interviews were held individually with male landowners who had obtained land at the time of settlement $(n=9)$, male land inheritors $(n=7)$, nonlandowning or non-Emberá male immigrants who came after the first waves of settlement $(n=4)$, women (wives of landowners and inheritors, $n=8)$, and youth $(n=7)$. We discussed current and past land-use and management practices, factors influencing land-use/land cover, socioeconomic characteristics, land tenure, and means of subsistence. Interviews were coded in two iterations. Three canonical correspondence analyses compared demographic household characteristics, and interviewees' perceived social and ecological influences to the landscape. Four linear discriminant analyses (LDA) tested which economic, social-cultural, political, and ecological influences mentioned by interviewees (explanatory factors) could discriminate among interviewees' genders, excluding youth (see Appendix 2). We explored gendered differences in perceptions with eight female participants who showed interest in a focus group discussion (see Appendix 1).

\section{RESULTS}

\section{Participatory mapping of communal lands}

We found a high concentration of pasture in Catrigandí and of fallow land on lands recently allotted to new families north of the community (Fig. 2). Forest was concentrated to the north, furthest

Fig. 2. Participatory map of the community land (tierras colectivas) of Piriatí-Emberá.

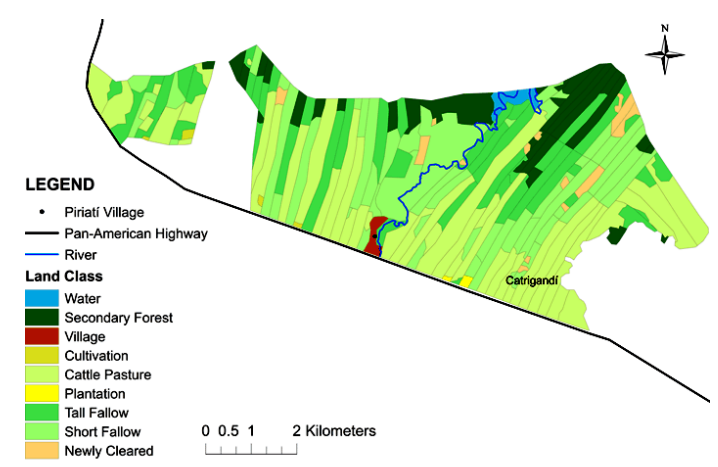


from the Highway. Pasture accounted for $38 \%$ of the communal lands, short and tall fallow for $48 \%$, and secondary forest for $11 \%$ which was labeled as such because participants alleged that forest was selectively logged before resettlement. The proportion of pasture was highly variable across parcels, ranging from 0 to $100 \%$.

\section{Household interviews}

\section{Demographic influences}

Canonical correspondence analysis (CCA) produces two canonical axes that represent linear combinations of explanatory variables (e.g., demographics). Vectors visually represent the degree to which explanatory variables account for variation in response variables (i.e., land cover). CCA does not test significant differences (see Appendix 2). In the CCA examining the relationship between household demographics and land cover in the plot, cumulative proportion of variance in land cover explained by the two canonical axes was $86.7 \%$; the first axis explained $47.9 \%$ (Fig. 3, see Appendix 2). The explanatory variable with the highest loading on the first canonical axis was number of people living at home, with an interset correlation coefficient of 0.5116 , followed by location (0.4628), number of people available to help $(-0.4517)$, and wealth ranking $(-0.3703)$.

Fig. 3. Biplot of canonical correspondence analysis between land cover and demographic characteristics at the household level. The axes are linear combinations of the demographic explanatory variables in italics (e.g., \# Elders). The relationship between the explanatory variables and the axis can be estimated by drawing a perpendicular line from the tip of the vector to each axis. The relative importance of the explanatory variables on the canonical axes can be estimated by the length and position of the vectors. The bold arrows position the land cover dependent variables (e.g., \% pasture) on the 2D space to help visualize the degree to which the explanatory variables explain the variation in the dependent variables. Origin represents whether the interviewee's family is originally from the Darién province (value of 1 ; otherwise value of 0 ). Location represents whether the interviewee lives closer to the Highway (Site 1; value of 0 ) or further (Site 2; value of 1). \# Help represents the number of people available to help work the land.

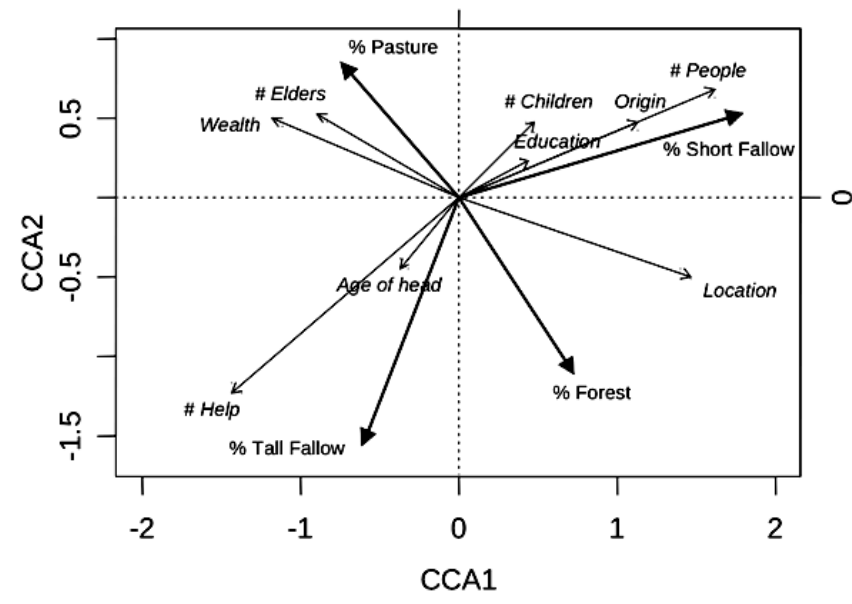

On the second canonical axis number of people living at home $(0.2162)$ and number of people available to help $(-0.3872)$ had the highest loadings. We found a greater percentage of pasture, used for livestock or rental to others, on plots of interviewees who were wealthier and had more elders living at home. Those plots with a greater percentage of short fallow, associated with agricultural land, had more people living at home and were from the Darién. Those plots with more tall fallow had a greater number of people available to help, and those with more secondary forest tended to be from Site 2.

\section{Perceived influences}

Thirty-three interviewees referenced the desire, necessity, or advantages of reforestation within the community or communal lands; 28 explicitly expressed their own desire to reforest. The greatest proportion of interviewees referred to economic (versus social-cultural, political, or ecological) factors that affect their land-use decision-making or are perceived to influence others' decisions $(n=33,94 \%)$. Landowners $(n=17,100 \%)$ and women $(n=8,100 \%$; Table 1$)$ had the greatest proportion of interviewees who mentioned such factors. Of these, potential income $(n=30$, $86 \%)$, subsistence $(n=29,83 \%)$ and availability of resources and labor $(n=29,83 \%)$ were most mentioned. Economic influences explained forest cover in the communal lands, partly through encouraging felling and planting of trees such as espavé (Anacardium excelsum), cocobolo (Dalbergia retusa), and teak to sell to external buyers.

Table 1. Economic factors that influence land-use decisions, as mentioned by interviewees.

\begin{tabular}{|c|c|c|c|}
\hline$\overline{\text { Factor }}$ & $\begin{array}{c}\text { Landowners }{ }^{\dagger} \\
(\%)\end{array}$ & $\begin{array}{l}\text { Women } \\
(\%)\end{array}$ & $\begin{array}{c}\text { Youth }^{\S} \\
(\%)\end{array}$ \\
\hline Resources and labor & 100 & 100 & 14 \\
\hline $\begin{array}{l}\text { Natural resource use by } \\
\text { outsiders }\end{array}$ & 53 & 38 & 0 \\
\hline $\begin{array}{l}\text { Encroaching frontier } \\
\text { settlement }\end{array}$ & 12 & 13 & 0 \\
\hline $\begin{array}{l}\text { Lack of off-farm } \\
\text { employment }\end{array}$ & 0 & 13 & 0 \\
\hline Subsistence & 94 & 88 & 57 \\
\hline Potential income & 100 & 88 & 57 \\
\hline $\begin{array}{l}\text { Presence of external } \\
\text { markets }\end{array}$ & 12 & 0 & 0 \\
\hline Tourism & 0 & 0 & 0 \\
\hline Off-farm economies & 6 & 13 & 0 \\
\hline $\begin{array}{l}\text { Presence of external } \\
\text { organizations }\end{array}$ & 29 & 0 & 14 \\
\hline Total & 100 & 100 & 71 \\
\hline \multicolumn{4}{|c|}{$\begin{array}{l}\text { "Total number of landowner respondents } n=17 \text {. } \\
\text { "Total number of female respondents } n=8 \text {. } \\
\text { \$Total number of youth respondents } n=7 \text {. } \\
\text { "Total" is the percentage of respondents in each category that referred } \\
\text { to economic factors as influences. }\end{array}$} \\
\hline
\end{tabular}

Historical timber extraction by outsiders and colonist encroachment contributed to lack of forest, and restricted access to seeds has limited reforestation of harvestable wood. Campesinos who rent or buy plots of communal land have felled the forest and/or put pasture in their parcels. Meanwhile, limited land availability means forest reserves are left in parcels as land to cultivate in the future. 
For people there's no other option for sustenance, you know? To get their nourishment [cultivation] is the only form of work they have. - a youth

Economic factors helped explain high pasture cover. Traditionally, livelihoods were subsistence based but now indigenous farmers are members of a market economy seeking to buy goods and services. Cattle ranching or renting land to ranchers is considered a less time-consuming, less physically demanding way to earn extra income given limited resources and labor. Others are deterred from pasture conversion due to the monetary investment and limited land availability, which would mean having insufficient land for cultivation or for children.

The only solution that will let me support my children or send them to university is to have a few more animals and in case of hardship I can sell . . _ - a landowner

Twenty interviewees $(57 \%)$ referred to the social-cultural factors affecting land uses, of which women comprised the greatest proportion ( $n=7,88 \%$; Table 2). Tradition was the factor most mentioned $(n=10,29 \%)$. Traditional uses justify reforestation of harvestable tree species, like espavé for dugout canoes or cocobolo for handicrafts. Presence of traditional medicine in forests discourages some landowners from deforesting. Traditional shifting cultivation accounts for forest presence, since it involves replanting seeds of naturally growing trees, fallowing land to enable tree regrowth, leaving trees, and planting trees as borders.

Table 2. Social-cultural factors that influence land-use decisions, as mentioned by interviewees.

\begin{tabular}{|c|c|c|c|}
\hline Factor & $\begin{array}{c}\text { Landowners }^{\dagger} \\
(\%)\end{array}$ & $\begin{array}{l}\text { Women }^{\ddagger} \\
(\%)\end{array}$ & $\begin{array}{c}\text { Youth }^{\S} \\
(\%)\end{array}$ \\
\hline Proximity to outsiders & 6 & 0 & 0 \\
\hline $\begin{array}{l}\text { Influence of outsider's } \\
\text { worldview }\end{array}$ & 29 & 13 & 0 \\
\hline Population increase & 0 & 38 & 14 \\
\hline $\begin{array}{l}\text { Lack of social } \\
\text { organization }\end{array}$ & 6 & 50 & 0 \\
\hline Tradition & 29 & 38 & 14 \\
\hline Internal laws & 24 & 25 & 0 \\
\hline Total & 59 & 88 & 14 \\
\hline \multicolumn{4}{|c|}{$\begin{array}{l}\text { "Total number of landowner respondents } n=17 \text {. } \\
\text { "Total number of female respondents } n=8 \text {. } \\
\text { \$Total number of youth respondents } n=7 \text {. } \\
\text { "Total" is the percentage of respondents in each category that referred } \\
\text { to social-cultural factors as influences. }\end{array}$} \\
\hline
\end{tabular}

Social-cultural influences on pasture levels were also mentioned. Influenced by observing campesinos with pasture, some consider it a lucrative alternative to subsistence agriculture. Weak internal laws (local, traditional rules) and lack of social organization, due to perceived lack of communication and inclusion of people outside the community in communal activities, have encouraged the selling of land to campesinos who have converted land to pasture. Some are reticent to sell or rent out land because it violates internal communal laws.

Even though you don't know how to read, you're working with cows so you have money... ., [the campesino] told me. - a landowner
Fourteen interviewees ( $40 \%)$ indicated political factors affecting land uses (Table 3 ). Of these, public policies was most mentioned, including land endowment, lack of support of indigenous populations, and governmental timber extraction $(n=11,31 \%)$. The 1975 Agreement of Majecito, between community members and the government, is one policy that establishes pasture as a legitimate communal land use. Before the government granted legal land title, some people sold parcels to colonist cattle ranchers, lest the government re-appropriate their lands first.

Table 3. Political factors that influence land-use decisions, as mentioned by interviewees.

\begin{tabular}{|c|c|c|c|}
\hline Factor & $\begin{array}{c}\text { Landowners }^{\dagger} \\
(\%)\end{array}$ & $\begin{array}{c}\text { Women } \\
(\%)\end{array}$ & $\begin{array}{c}\text { Youth }^{\S} \\
(\%)\end{array}$ \\
\hline Public policies & 53 & 25 & 0 \\
\hline $\begin{array}{l}\text { Lack of } \\
\text { property title }\end{array}$ & 12 & 50 & 0 \\
\hline $\begin{array}{l}\text { Local } \\
\text { politicians }\end{array}$ & 6 & 0 & 0 \\
\hline Total & 53 & 50 & 0 \\
\hline \multicolumn{4}{|c|}{$\begin{array}{l}\text { Total number of landowner respondents } n=17 \text {. } \\
\text { "Total number of female respondents } n=8 \text {. } \\
\text { \$Total number of youth respondents } n=7 \text {. } \\
\text { "Total" is the percentage of respondents in each category that referred } \\
\text { to political factors as influences. }\end{array}$} \\
\hline
\end{tabular}

A second CCA used interviewees' perceived economic, socialcultural and political influences on land uses and compared them to land cover in their parcels (Fig. 4). The cumulative proportion of variance in land cover explained by the two canonical axes was $66.2 \%$, with the first axis explaining $35.9 \%$. The explanatory variables with the highest loadings on the first axis were presence of external organizations (0.6638), population increase (0.4108), availability of resources and labor $(-0.5034)$, and lack of social organization $(-0.3283)$. The highest loadings on the second axis were population increase $(0.3162)$, subsistence $(0.3118)$, potential income $(-0.2528)$, and local politicians $(-0.2145)$. We found a greater percentage of tall fallow in the plots of interviewees who referred more to the influence of presence of external organizations on land use. External organizations were nongovernmental organizations that have introduced reforestation, like the Global Brigades and Peace Corps. A greater percentage of secondary forest was found on plots of those who mentioned population increase. More short fallow for agriculture was found on plots of those who referred to availability of resources and labor and proximity to outsiders, and more pasture on that of those who referred to local politicians' influence. In the last decade, a local politician rented approximately eight plots and established cattle pastures managed by indigenous landowners.

Nineteen $(54 \%)$ interviewees, the greatest proportion of whom were landowners $(n=11,65 \%)$, referred to ecological factors affecting land uses (Table 4). Of these, soil characteristics $(n=5$, $14 \%)$ and distance from house to plot $(n=5,14 \%)$ were most mentioned. Ecological considerations justified pasture conversion partly because elder landowners claimed that land in Piriatí is less fertile than their place of origin (as cited in Wali 1993). Crop 
Fig. 4. Biplot of canonical correspondence analysis between land cover (dependent variables) and social-cultural, economic, and political influences on land use (explanatory variables), as mentioned by interviewees. Influences are in italics, while percent land cover is represented by bold arrows. $a=$ Availability of resources and labor. $b=$ natural resource use by outsiders. $c=$ encroaching frontier settlement. $d=$ off-farm employment opportunities. $e=$ population increase. $f=$ potential income. $g=$ presence of external markets. $h=$ proximity to outsiders. $i=$ influence of outsiders' worldview. $j=$ subsistence. $k=$ lack of social organization. $l=$ presence of external organizations. $m=$ tradition. $n=$ internal laws. $o=$ public policies. $p=$ lack of property title. $q=$ local politicians.

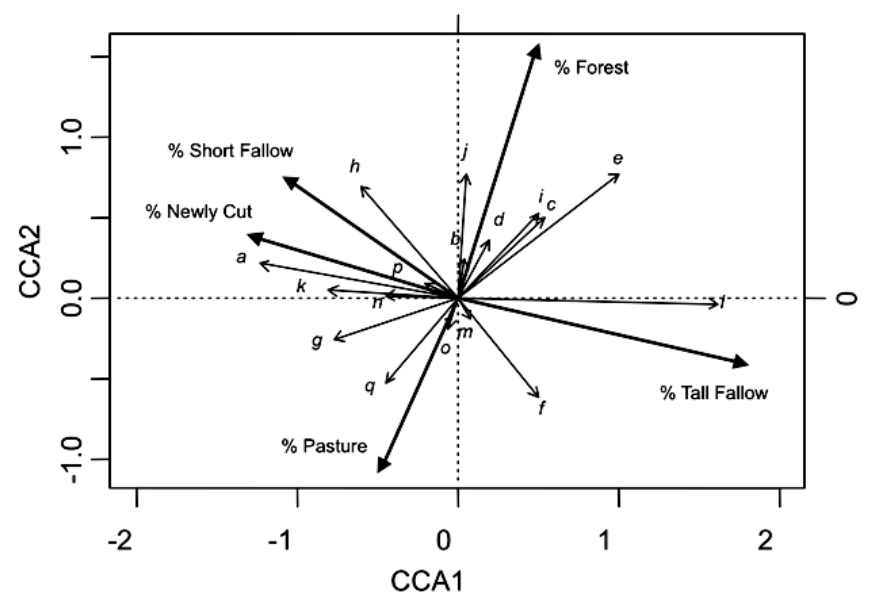

disease of yam (ñame, Dioscorea alata), a once important cash crop (Herlihy 1986), and invasion of "canal grass" (paja canalera, Saccharum spontaneous) have encouraged some landowners to forsake cultivation for cattle ranching. Distance to plot was invoked by landowners who require pasture for horses used to access remote plots. Topography was invoked by a landowner who was unable to have cattle on hilly terrain, and restoration of natural beauty/state was invoked as a motivator for future reforestation.

In the CCA that compared ecological influences on land uses mentioned by interviewees to land cover in the parcel (Fig. 5), cumulative proportion of variance in land cover explained by the two canonical axes was second highest of the three CCAs at $83.9 \%$; the first axis explained $55 \%$. The explanatory variables with the highest loading on the first axis were distance to plot (0.3959), soil characteristics (-0.4643), and topography (-0.3541). On the second axis, the highest loadings were crop disease $(0.2797)$, distance to plot $(-0.4396)$, and effects on river $(-0.3042)$. Plots with a greater percentage of pasture tended to belong to interviewees who suggested the influence of crop disease, while plots with a greater percentage of tall fallow tended to belong to those who referred to distance to plot. Those plots with more short fallow tended to belong to those who mentioned topography and natural beauty/state.

The economic LDA showed that mention of off-farm employment was a significant predictor of female interviewees; presence of external organizations and markets were most significant predictors of males (Table 5). Jacknife cross-validated classification showed that $60.7 \%$ of women and men were classified correctly. The social-cultural LDA showed that population and social organization were significant predictors of females, and influence of outsiders' (colonists') worldviews was a predictor of males $(60.7 \%$ correct classification). From the political LDA, property title was a significant predictor of females, and public policies best predicted males $(71.4 \%$ correct classification). The ecological LDA showed effects on animals as a predictor of females, and natural beauty/state, effects on river, heat/shade and topography were the most significant predictors of males $(64.3 \%$ correct classification).

Table 4. Ecological factors that influence land-use decisions, as mentioned by interviewees.

\begin{tabular}{lccc}
\hline \hline Factors & $\begin{array}{c}\text { Landowners }^{\dagger} \\
(\%)\end{array}$ & $\begin{array}{c}\text { Women }^{\ddagger} \\
(\%)\end{array}$ & $\begin{array}{c}\text { Youth }^{\S} \\
(\%)\end{array}$ \\
\hline Crop diseases & 12 & 13 & 0 \\
Soil & 18 & 13 & 0 \\
characteristics & 12 & 0 & 0 \\
Invasive species & 6 & 0 & 0 \\
Topography & 12 & 0 & 14 \\
Effects on river & 0 & 13 & 0 \\
Effects on & 12 & 13 & 14 \\
animals & 6 & 0 & 14 \\
Distance to plot & 18 & 0 & 0 \\
Heat/shade & & & 14 \\
Natural beauty/ & 65 & 50 & \\
state & Total & &
\end{tabular}

Total number of landowner respondents $n=17$.

"Total number of female respondents $n=8$.

${ }^{\S}$ Total number of youth respondents $n=7$.

"Total" is the percentage of respondents in each category that referred to ecological factors as influences.

\section{DISCUSSION}

\section{Demographics and history}

Piriatí's pasture-dominated landscape is a product of a web of social-ecological factors informing individual household decisions, as suggested by the considerable variation in pasture proportion across individual parcels. The positive relationship of wealth and number of elders with a plot's proportion of pasture supports the hypothesis that households further in their life cycle have resources to invest in cattle ranching (Perz 2001, Walker et al. 2002). Households with no elders in Piriatí tended to be younger, formed by children after marrying and establishing their own nuclear families (as occurred traditionally; see Herlihy 1986). The association of number of people at home with proportion of short fallow suggests that households use agriculture as a livelihood strategy shaped by the presence of more dependents. Increased household size has encouraged deforestation in rural Latin America by necessitating conversion to cropland for consumption or sale of surplus (Carr 2005, Mena et al. 2006). In a study of land-use/land cover change in Mexico, population pressure was associated with presence of pasture and agriculture, possibly for household consumption (Ellis et al. 2010). 
Fig. 5. Biplot of canonical correspondence analysis between land cover and ecological perceptions of influences on land use, as mentioned by interviewees. Ecological explanatory variables are in italics, while percent land cover dependent variables are represented by bold arrows. Soil characteristics includes the soil fertility and water content of the soil.

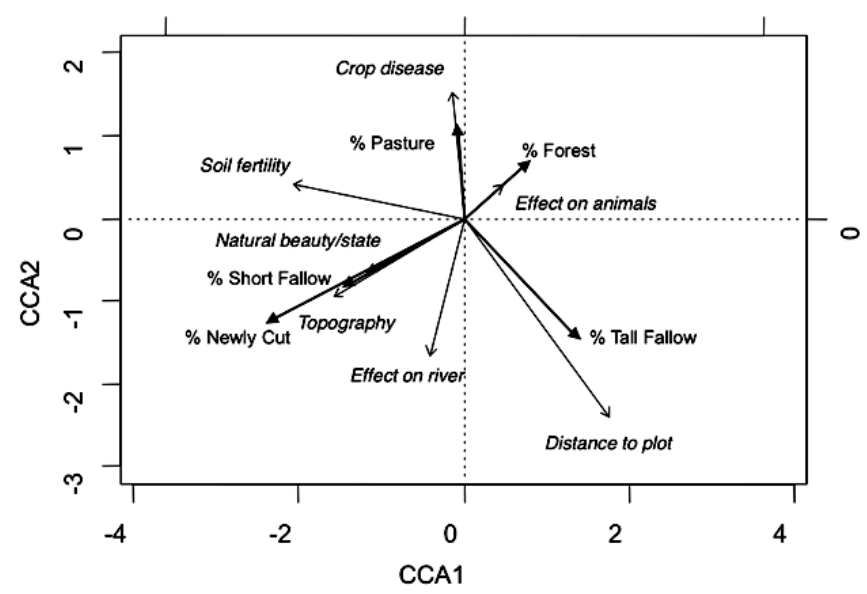

The analysis also illustrates settlement history's legacy on the communal landscape. A group of Emberá first settled in the Bayano from the Darién province following Pan-American Highway expansion into eastern Panama in the 1950s (Araúz et al. 1973, Pastor 1985) to have better access to urban markets and open areas for agriculture (Herlihy 1986, Wali 1993). Some Emberá settled along the Bayano River, where they practiced swidden agriculture. After dam construction, they eventually settled in two communities in the watershed, including Piriatí (Wali 1989, 1993). Insecurity over land rights meant that resettled Emberá did not engage in intensive agriculture (Wali 1989). They initially practiced minimal cattle ranching due to lack of experience with the practice (Wali 1993).

Our analysis shows that the original households in Piriatí, whose lands are not concentrated in a specific area, tend to have more customary land use, i.e., more forest and less pasture, than more recent settlers. As Emberá along the Bayano were deciding where to resettle, the Piriatí group leader is said to have sought out Emberá who wanted to create a community based on shared traditional values. These original households tend to have traditional houses and participate more in communal activities. Furthermore, those who originally came from the Darién province tend to have more short fallow than those who were not from that province, which can be explained by their greater engagement in traditional agricultural activities as opposed to cattle ranching. The Darién province, not entirely traversed by the Highway, includes two Emberá-Wounaan indigenous reserves (comarcas). Communities in Darién are therefore more isolated from Latino influences. Thus degree of adherence to traditional worldviews and agriculture based on landowners' history apparently resulted in differential land-use practices. Given the community's objective of reforestation, organizing a more unified community that engages in traditional, communal activities can perhaps reinforce forest conservation.
Table 5. Correlations of influences on land uses with discriminant functions. ${ }^{\dagger}$

\begin{tabular}{lc}
\hline \hline Explanatory factor & Correlation \\
\hline Off-farm employment & -0.483 \\
Presence of external & 0.487 \\
organizations & \\
Presence of external markets & 0.290 \\
Population & -0.750 \\
Social organization & -0.727 \\
Outsiders' worldviews & 0.250 \\
Property title & -0.730 \\
Public policies & 0.370 \\
Effects on animals & -0.662 \\
Natural beauty/state & 0.476 \\
Effects on river & 0.381 \\
Heat/shade & 0.381 \\
Topography & 0.264 \\
\hline
\end{tabular}

'Separate linear discriminant analyses were conducted for economic, social-cultural, political, and ecological factors, with female and male interviewees as groups. The most significant predictors are shown.

\section{Tradition and subsistence}

Rural livelihood strategies constitute bundles of activities that enable survival and security, including subsistence or commercial agriculture, hunting and gathering, timber harvesting, selling of arts and crafts, day labor, and city jobs (de Sherbinin et al. 2008). Once in the market, indigenous peoples become increasingly reliant on market products (Godoy 2001). Livelihood strategies are then negotiated to incorporate these new needs. Natural resources like timber and nontimber forest products provide an avenue for income generation in rural Latin America, becoming a form of insurance or "livelihood buffer" for wellbeing (de Sherbinin et al. 2008). Livelihood profiles can be highly heterogeneous between and within indigenous villages, however. Among the Honduran Tawahka Sumu, those who generated the most income from forest products were those least financially dependent upon forest goods, given diversified income sources (McSweeney 2002).

Livelihood strategies respond to environmental, socioeconomic, and political circumstances (Nygren 2000). They form as a result of coping behavior, risk management, and market opportunities, negotiated by social institutions like kin networks and gender norms (Ellis 1998). Influence of social-cultural institutions given externally imposed factors has been found in numerous indigenous settings. In southwest China, renegotiation of belief in sacred forests enabled forest restoration, following government policies like sedentarization of swidden cultivation (Liu et al. 2000, as cited in Xu et al. 2009). Increased agroforest tea prices encouraged indigenous Akha farmers in China to use social institutions like ecological knowledge to network with the tea industry (Ahmed et al. 2010). Livelihoods of indigenous Wounaan of eastern Panama, a neighboring group with whom there is some intermarriage (Herlihy 1986), display a similar proclivity for cultural values, which encourage traditional basket weaving but also nontraditional shrimping in tune with norms of independence (Runk et al. 2007). 
Interview results illustrate the importance of cultural worldviews on the landscape. Despite ubiquitous emphasis on economic factors, community members often said conversion to pasture would divert land from traditional subsistence agriculture.

\section{Well, I plan on continuing to work the land [after putting pasture], because it's my everyday sustenance, no? - a landowner}

There was a steady allusion to the role of tradition even when not explicitly articulated. Often community members explained their decisions by stating, "This is what we do" or "This is what we have always done". Importance of tradition on the landscape was especially evident in the difficulty some landowners had in accounting for forest reserves in their parcels. This struggle to justify a practice elders claim was traditionally carried out to ensure sustainability of the forest and its cultural resources, and to preserve land for future cultivation, suggests tradition's understated role in guiding land-use decisions, albeit at times through convention more than active decision-making.

Ultimately, however, the focus of interviewees on income, subsistence, and resources, and the prevalence of pasture in Piriatí, suggest that social-cultural concerns have become secondary to economic concerns in land-use decision-making and, therefore, genesis of the landscape. The context in which institutions like internal laws were mentioned was largely one of ineffectiveness; social institutions have not been harnessed to ensure livelihoods like in aforementioned indigenous circumstances. Cattle raising or selling of agricultural surplus, both drivers of deforestation in Piriatí, were justified as the optimal livelihood strategy that enables subsistence. In the Bayano, indigenous and colonist communities displayed similar patterns of timber extraction based on proximity to market, despite ethnic differences (Simmons 1997). In a context of limited resources, historical natural resource exploitation (Wali 1993), and exclusionary public policies - like granting of private land title for productive use (Wali 1993) and urban rather than rural economic growth and investment (Runk 2012)-community members perceive little practicality in long-term cultural preservation at the expense of immediate survival. Any future reforestation plans must necessarily value subsistence needs in order to be relevant to villagers' concerns.

\section{Gendered perspectives}

Our LDA suggests that Piriatí's women are more aware of internal social-cultural factors that shape land uses than men, who are more aware of external and ecological constraints. Focus group discussion and interviews showed that this gendered divide can be explained by: women's greater social role within the community, women's decreased participation in cultivation due to new technologies and economic opportunities in timber extraction, and women's less frequent interaction with outsiders compared to men due to cultural norms.

Men in Piriatí make land-use decisions, at times informed by women's judgment. Women were often unable to describe in detail land-use and management practices. They help with sowing and harvesting but not land clearing, and sometimes cook for men who are working (as occurred traditionally; see Araúz et al. 1973, Herlihy 1986, Kane 1986). Likewise, in Bolivia there was a subtle gendered subdivision of tasks within particular shared activities (Paulson 2003), and Guatemalan women are not responsible for the most important household decisions (Taylor et al. 2006). This limited involvement of women in cultivation may entail less ecological knowledge and less awareness of ecological influences on land-use decisions. Generally, women are more engaged in community groups, perhaps entailing a keener awareness of social aspects of community life. Women's social role helps explain why, in Mexico, women were more concerned with pollution effects, and men with the threat of deforestation. Specifically, women were those looking after sick children (Arizpe et al. 1996). Men in Piriatí alluded more to the influence of external organizations on forest presence through reforestation, suggesting that they are more aware of the ecological rather than social effects of such organizations.

Gendered labor divisions change over time. Women spend less time in fields than previously, in part due to increased emphasis on timber extraction rather than agriculture, which yields slower financial returns. Timber extraction is a male enterprise, as it requires camping away for weeklong stretches. Women have not become caretakers of farms following men's shift to incomegenerating labor, as has occurred elsewhere (see Razavi 2003), due to a general sense of farming's decreased value. Rather, increased timber extraction has heightened women's roles in the social domain as housekeepers and has thereby influenced women's livelihoods and perceived influences on the land, reflecting the coproduction of land use and livelihood (see McCusker and Carr 2006).

With agriculture it's not the same because you can go yourself, take your kids, leave them in a ranchito there. You're helping. But there [in timber extraction] it's another method. - a woman

Economic changes-including new technology, like machine huskers, vendors who come to the community, and stores that sell goods - have decreased the need to work the lands or fish, of which the latter was once an important subsistence activity (Herlihy 1986). Similarly, Emberá women in the Darién spend less time on the land, due to the presence of stores that limit the need for household gardens and sugarcane production, less fishing and gathering associated with diminished resources, and an increasing view of the forest as an unsuitable place for women (Colin 2013). The result is continued consignment of women's roles in the household and less interaction with the land than men. Araúz et al. (1973) argued that the household responsibility of Emberá women gave them power to help with household decisions and an advantage in the home and society. Gendered social roles influence who has power to make decisions, and gendered perspectives of land-use decision makers can shape the subsequent landscape.

Women's lower interaction with outsiders perhaps explains why they referred more to internal social influences, like social organization and population increase, while more men referred to the external influence of outsiders, external markets, and public policies on land-use decisions. Emberá men increasingly engage with the outside world as leaders who represent households and communities (Kane 1986, 1994). Meanwhile, women say they are discouraged from leaving the community, as the city is considered dangerous and there is a fear that women will marry nonindigenous men. Therefore, as also suggested in the case of the Chilean Mapuche (Vergara and Barton 2013), because women have stayed in the community, they are more familiar than men 
with communal matters. In Sri Lanka, women's greater involvement in the community compared to men has translated to greater traditional knowledge, which women apply to subsistence activities, thereby contributing to the local system's sustainability (Wickramasinghe 2004). Men's and women's relative degrees of interaction with the external world form part of the context that influences interaction with the land.

Men, informed by ecological and external economic and political concerns, are those with power and knowledge to make land-use decisions. Future reforestation could therefore benefit from inclusion of female perspectives that encompass social-cultural considerations, given that social organization and tradition may discourage pasture conversion.

\section{CONCLUSION}

A social-ecological perspective that considers local context avoids generalized prescriptions of deforestation irrelevant on the ground (Ostrom and Cox 2010). The Piriatí landscape is a result of individual household land-use decisions constrained by ecological land characteristics like crop disease, household socioeconomics like wealth, social-cultural communal context like weak internal laws, and broader political and economic circumstances like government policies and resource availability. Decisions are principally informed by subsistence concerns, thus accounting for pasture dominance, but are also influenced by traditional norms and settlement history, which has led to land cover mosaics across the landscape. Gendered perspectives mediate awareness of influences on the landscape. Any future communal reforestation efforts must address these diverse concerns in order to be effective.

Responses to this article can be read online at: http://www.ecologyandsociety.org/issues/responses. $\mathrm{php} / 7897$

\section{Acknowledgments:}

We thank Rodolfo Cunampio for his continued support and guidance throughout the research process, and the community members of Piriati-Emberá for their participation and interest. We also thank Ignacia Holmes, Jeanine Rhemtulla, and Ana Spalding for their guidance on methodology and with the manuscript. We acknowledge a Discovery Grant (to C. Potvin) and scholarship (to D. Sharma) from the Natural Sciences and Engineering Resource Council of Canada, the Margaret A. Cargill Foundation project grant (to $C$. Potvin), a scholarship of the Fonds de recherche du Québec-Natures et technologies (to D. Sharma), a travel grant from McGill University (to D. Sharma), and fellowships from the Ford Foundation International Fellowship Program and the Global Environmental and Climate Change Centre (to G. Vergara-Asenjo).

\section{LITERATURE CITED}

Abizaid, C. A., and O. T. Coomes. 2004. Land use and forest fallowing dynamics in seasonally dry tropical forests of the southern Yucatán Peninsula, Mexico. Land Use Policy 21:71-84. http://dx.doi.org/10.1016/j.landusepol.2003.06.001
Ahmed, S., J. R. Stepp, R. A. J. Toleno, and C. M. Peters. 2010. Increased market integration, value, and ecological knowledge of tea agroforests in the Akha Highlands of southwest China. Ecology and Society 15(4):27. [online] URL: http://www. ecologyandsociety.org/vol15/iss4/art27/

Araúz, R. G., M. A. de Arosemena, A. Montalvan, J. Arauz, and E. Gonzalez. 1973. Estudio de Antropologia Social y Aplicada de la Comunidad Choco de Majecito que Sera Movilizada con la construccion de la Represa Hidroelectrica del Bayano. Instituto Nacional de Cultura y Deportes, Panama.

Arizpe, L., F. Paz, and M. Velázquez. 1996. Culture and global change: social perceptions of deforestation in the Lacandona rain forest in Mexico. University of Michigan Press, Ann Arbor, Michigan, USA.

Arroyo-Mora, J. P, G. A. Sánchez-Azofeifa, B. Rivard, J. C. Calvo, and D. H. Janzen. 2005. Dynamics in landscape structure and composition for the Chorotega region, Costa Rica from 1960 to 2000. Agriculture, Ecosystems and Environment 106:27-39.

Behrens, C. A., M. G. Baksh, and M. Mothes. 1994. A regional analysis of Bari land use intensification and its impact on landscape heterogeneity. Human Ecology 22:279-316. http://dx. doi.org/10.1007/BF02168854

Carr, D. L. 2005. Forest clearing among farm households in the Maya Biosphere Reserve. Professional Geographer 57:157-168. http://dx.doi.org/10.1111/j.0033-0124.2005.00469.x

Castillo, A., A., Magaña, A. Pujadas, L. Martínez, and C. Godínez. 2005. Understanding the interaction of rural people with ecosystems: a case study in a tropical dry forest of Mexico. Ecosystems 8(6):630-643. http://dx.doi.org/10.1007/s10021-005-0127-1

Chazdon, R. L., C. A. Harvey, O. Komar, D. M. Griffith, B. G. Ferguson, M. Martinez-Ramos, H. Morales, R. Nigh, L. SotoPinto, M. van Breugel, and S. M. Philpott. 2009. Beyond reserves: a research agenda for conserving biodiversity in human-modified tropical landscapes. Biotropica 41:142-153. http://dx.doi. org/10.1111/j.1744-7429.2008.00471.X

Chowdhury, R. R., and B. L. Turner. 2006. Reconciling agency and structure in empirical analysis: smallholder land use in the southern Yucatán, Mexico. Annals of the Association of American Geographers 96(2):302-322. http://dx.doi.org/10.1111/ j.1467-8306.2006.00479.x

Colin, F. -L. 2013. Commodification of indigenous crafts and reconfiguration of gender identities among the Emberá of eastern Panama. Gender, Place \& Culture 20:487-509. http://dx.doi. org/10.1080/0966369x.2012.694359

de Sherbinin, A., L. Vanwey, K. McSweeney, R. Aggarwal, A. Barbieri, S. Henry, L. M. Hunter, and W. Twine. 2008. Rural household demographics, livelihoods and the environment. Global Environmental Change 18:38-53. http://dx.doi.org/10.1016/ j.gloenvcha.2007.05.005

Durand, L., and E. Lazos. 2008. The local perception of tropical deforestation and its relation to conservation policies in Los Tuxtlas Biosphere Reserve, Mexico. Human Ecology 36:383-394. http://dx.doi.org/10.1007/s10745-008-9172-7 
Ellis, E. A., K. A. Baerenklau, R. Marcos-Martínez, and E. Chávez. 2010. Land use/land cover change dynamics and drivers in a low-grade marginal coffee growing region of Veracruz, Mexico. Agroforestry Systems 80:61-84. http://dx.doi.org/10.1007/ $\underline{\text { s10457-010-9339-2 }}$

Ellis, F. 1998. Household strategies and rural livelihood diversification. Journal of Development Studies 35:1-38. http://dx. doi.org/10.1080/00220389808422553

Etongo, D. B., and E. K. Glover. 2012. Participatory resource mapping for livelihood values derived from the forest in EkondoTiti subregion, Cameroon: a gender analysis. International Journal of Forestry Research 2012:1-9. http://dx.doi. org/10.1155/2012/871068

Evans, K., W. de Jong, P. Cronkleton, D. Sheil, T. Lynam, T. Kusumanto, and C. J. Pierce Colfer. 2006. Guide to participatory tools for forest communities. Center for International Forestry Research (CIFOR), Bogor, Indonesia.

Fischer, A., and L. Vasseur. 2000. The crisis in shifting cultivation practices and the promise of agroforestry: a review of the Panamanian experience. Biodiversity and Conservation 9:739-756. http://dx.doi.org/10.1023/A:1008939425511

Food and Agriculture Organization of the United Nations. 2010. Global forest resources assessment 2010, main report. FAO Forestry Paper 163. Forestry Department, FAO, Rome, Italy.

Geist, H. J., and E. F. Lambin. 2002. Proximate causes and underlying driving forces of tropical deforestation. BioScience 52 (2):143-150. http://dx.doi.org/10.1641/0006-3568(2002)052[0143: pcaudf]2.0.co:2

Godoy, R. A. 2001. Indians, markets and rainforests: theory, methods, analysis. Cambridge University Press, New York, New York, USA.

Gray, C. L., R. E. Bilsborrow, J. L. Bremner, and F. Lu. 2008. Indigenous land use in the Ecuadorian Amazon: a cross-cultural and multilevel analysis. Human Ecology 36:97-109. http://dx.doi. org/10.1007/s10745-007-9141-6

Grove, J. M., and W. R. Burch, Jr. 1997. A social ecology approach and applications of urban ecosystem and landscape analyses: a case study of Baltimore, Maryland. Urban Ecosystems 1:259-275. http://dx.doi.org/10.1023/A:1018591931544

Herlihy, P. H. 1985. Settlement and subsistence change among the Chocó Indians of the Darién Province, eastern Panama: an overview. Pages 11-16 in Yearbook, Conference of Latin Americanist Geographers Vol. 11.

Herlihy, P. H. 1986. A cultural geography of the Embera and Wounan (Choco) Indians of Darien, Panama: with emphasis on recent village formation and economic diversification. Ph.D. dissertation. Louisiana State University and Agricultural and Mechanical College, Baton Rouge, Louisiana, USA.

Herrera, F. 1986. Análisis socioeconómico de la Cuenca Alta del Bayano. Memorias del Taller Sobre la Problematica de la Cuenca Hidrográfica de Bayano. Centro Agronómico Tropical de Investigación y Enseñanza, San José, Costa Rica.
Herrera, F. 2012. The development of indigenous territorial claims and the response of the state in Panama. Quaderns-e 17 (1):44-59.

Horton, L. 2006. Contesting state multiculturalisms: indigenous land struggles in eastern Panama. Journal of Latin American Studies 38(4):829-858. http://dx.doi.org/10.1017/s0022216x06001623

Ickowitz, A. 2006. Shifting cultivation and deforestation in tropical Africa: critical reflections. Development and Change 37 (3):599-626. http://dx.doi.org/10.1111/j.0012-155x.2006.00492.x

Kane, S. 1986. Emberá (Chocó) village formation: the politics and magic of everyday life in the Darién forest. Ph.D. dissertation. University of Texas at Austin, Austin, Texas, USA.

Kane, S. 1994. The phantom gringo boat: Shamanic discourse and development in Panama. Smithsonian Institution, Washington D. C., USA.

Lambin, E. F., H. J. Geist, and E. Lepers. 2003. Dynamics of landuse and land-cover change in tropical regions. Annual Review of Environment and Resources 28:205-41. http://dx.doi.org/10.1146/ annurev.energy.28.050302.105459

Lambin, E. F., B. L. Turner, H. J. Geist, S. B. Agbola, A. Angelsen, J. W. Bruce, O. T. Coomes, R. Dirzo, G. Fischer, C. Folke, P. S. George, K. Homewood, J. Imbernon, R. Leemans, X. B. Li, E. F. Moran, M. Mortimore, P. S. Ramakrishnan, J. F. Richards, H. Skanes, W. Steffen, G. D. Stone, U. Svedin, T. A. Veldkamp, C. Vogel, and J. C. Xu. 2001. The causes of land-use and land-cover change: moving beyond the myths. Global Environmental Change, Human and Policy Dimensions 11:261-269. http://dx.doi. org/10.1016/s0959-3780(01)00007-3

Leach, M., S. Joekes, and C. Green. 1995. Gender relations and environmental change. IDS Bulletin 26:1-8. http://dx.doi. org/10.1111/j.1759-5436.1995.mp26001001.X

Leonard, S., M. Parsons, K. Olawsky, and F. Kofod. 2013. The role of culture and traditional knowledge in climate change adaptation: insights from East Kimberley, Australia. Global Environmental Change 23:623-632. http://dx.doi.org/10.1016/j. gloenvcha.2013.02.012

Makana, J.-R., and S. C. Thomas. 2006. Impacts of selective logging and agricultural clearing on forest structure, floristic composition and diversity, and timber tree regeneration in the Ituri Forest, Democratic Republic of Congo. Biodiversity and Conservation 15(4):1375-1397.

McCusker, B., and E. R. Carr. 2006. The co-production of livelihoods and land use change: case studies from South Africa and Ghana. Geoforum 37:790-804. http://dx.doi.org/10.1016/j. geoforum.2005.09.007

McKay, A. 1984. Colonización de Tierras Nuevas en Panama. Pages 45-60 in S. Heckadon Moreno and A. McKay, editors. Colonizacion y Destrucción de Bosques en Panama. Asociación Panameña de Antropologia, Panama.

McSweeney, K. 2002. Who is "forest-dependent"? Capturing local variation in forest-product sale, eastern Honduras. The Professional Geographer 54(2):158-174. http://dx.doi. org/10.1111/0033-0124.00323 
Mena, C. F., R. E. Bilsborrow, and M. E. McClain. 2006. Socioeconomic drivers of deforestation in the northern Ecuadorian Amazon. Environmental Management 37(6):802-815. http://dx.doi.org/10.1007/s00267-003-0230-Z

Mertz, O., R. L. Wadley, U. Nielsen, T. B. Bruun, C. J. P. Colfer, A. de Neergaard, M. R. Jepsen, T. Martinussen, Q. Zhao, G. T. Noweg, and J. Magid. 2008. A fresh look at shifting cultivation: fallow length an uncertain indicator of productivity. Agricultural Systems 96:75-84. http://dx.doi.org/10.1016/j.agsy.2007.06.002

Meyfroidt, P. 2013. Environmental cognitions, land change and social-ecological feedbacks: local case studies of forest transition in Vietnam. Human Ecology 41(3):367-392. http://dx.doi. org/10.1007/s10745-012-9560-X

Moran, E. F. 2010. Environmental social science: humanenvironment interactions and sustainability. Wiley-Blackwell, Chichester, West Sussex, UK. http://dx.doi.org/10.1002/9781444319057

Munji, C. A., M. Y. Bele, M. E. Idinoba, and D. J. Sonwa. 2014. Floods and mangrove forests, friends or foes? Perceptions of relationships and risks in Cameroon coastal mangroves. Estuarine, Coastal and Shelf Science 140:67-75. http://dx.doi. org/10.1016/j.ecss.2013.11.017

Nelson, G. C., V. Harris, and S. W. Stone. 2001. Deforestation, land use, and property rights: empirical evidence from Darien, Panama. Land Economics 77:187-205. http://dx.doi.org/10.2307/3147089

Nygren, A. 2000. Development discourses and peasant-forest relations: natural resource utilization as social process. Development and Change 31:11-34. http://dx.doi. org/10.1111/1467-7660.00145

Ostrom, E., and M. Cox. 2010. Moving beyond panaceas: a multitiered diagnostic approach for social-ecological analysis. Environmental Conservation 37:451-463. http://dx.doi.org/10.1017/ $\underline{\mathrm{S} 0376892910000834}$

Pacheco, P., M. Aguilar-Støen, J. Börner, A. Etter, L. Putzel, and M. d. C. V. Diaz. 2011. Landscape transformation in tropical Latin America: assessing trends and policy implications for REDD+. Forests 2:1-29. http://dx. doi.org/10.3390/f2010001

Pastor, A. 1985. Desarollo del Programa de Reubicación Chocoe en el Bayano: Traslado de Majecito. La Loteria 350-351:61-76.

Paulson, S. 2003. Gendered practices and landscapes in the Andes: the shape of asymmetrical exchanges. Human Organization 62:242-254. http://dx.doi.org/10.17730/

humo.62.3.62mwrgc45nmym8xy

Peralta, P. A., and K. A. Kainer. 2008. Market integration and livelihood systems: a comparative case of three Asháninka villages in the Peruvian Amazon. Journal of Sustainable Forestry 27:145-171. http://dx.doi.org/10.1080/10549810802225267

Perz, S. G. 2001. Household demographic factors as life cycle determinants of land use in the Amazon. Population Research and Policy Review 20(3):159-186.

Potvin, C., P. Tschakert, F. Lebel, K. Kirby, H. Barrios, J. Bocariza, J. Caisamo, L. Caisamo, C. Cansari, J. Casamá, M. Casamá, L. Chamorra, N. Dumasa, S. Goldenberg, V. Guainora, P. Hayes, T. Moore, and J. Ruíz. 2006. A participatory approach to the establishment of a baseline scenario for a reforestation clean development mechanism project. Mitigation and Adaptation Strategies for Global Change 12:1341-1362. http://dx.doi. org/10.1007/s11027-006-9056-3

Razavi, S., editor. 2003. Agrarian change, gender and land rights. Journal of Agrarian Change 3(1-2):2-32.

Redman, C. L., J. M. Grove, and L. H. Kuby. 2004. Integrating social science into the Long-Term Ecological Research (LTER) Network: social dimensions of ecological change and ecological dimensions of social change. Ecosystems 7(2). http://dx.doi. org/10.1007/s10021-003-0215-Z

Rhemtulla, J. M., and D. J. Mladenoff. 2007. Why history matters in landscape ecology. Landscape Ecology 22:1-3. http://dx.doi. org/10.1007/s10980-007-9163-X

Rudel, T. K., R. Defries, G. P. Asner, and W. F. Laurance. 2009. Changing drivers of deforestation and new opportunities for conservation. Conservation Biology 23(6):1396-1405. http://dx. doi.org/10.1111/j.1523-1739.2009.01332.x

Runk, J. V. 2012. Indigenous land and environmental conflicts in Panama: neoliberal multiculturalism, changing legislation, and human rights. Journal of Latin American Geography 11(2):21-47.

Runk, J. V., G. Ortíz Negría, W. Quintero García, and C. Quiróz Ismare. 2007. Political economic history, culture, and Wounaan livelihood diversity in eastern Panama. Agriculture and Human Values 24:93-106. http://dx.doi.org/10.1007/s10460-006-9035-Z

Scoones, I. 1999. New ecology and the social sciences: what prospects for a fruitful engagement? Annual Review of Anthropology 28:479-507.

Seidenberg, C., O. Mertz, and M. B. Kias. 2003. Fallow, labor and livelihood in shifting cultivation: implications for deforestation in northern Lao PDR. Geografisk Tidsskrift-Danish Journal of Geography 103:71-80.

Simmons, C. S. 1997. Forest management practices in the Bayano region of Panama: cultural variations. World Development 25:989-1000. http://dx.doi.org/10.1016/S0305-750X(97)00002-8

Sirén, A. H. 2007. Population growth and land use intensification in a subsistence-based indigenous community in the Amazon. Human Ecology 35(6):669-680. http://dx.doi.org/10.1007/ s10745-006-9089-y

Smith, D. A. 2003. Participatory mapping of community lands and hunting yields among the Buglé of western Panama. Human Organization 62(4):332-343. http://dx.doi.org/10.17730/humo.62.4. cye $51 \mathrm{kbmmjkc168 \textrm {k }}$

St-Laurent, G. P., N. Gelinas, and C. Potvin. 2013. REDD+ and the agriculture frontier: understanding colonists' utilization of the land. Land Use Policy 31:516-525. http://dx.doi.org/10.1016/ j.landusepol.2012.08.017

Sydenstricker-Neto, J. 2012. Population and deforestation in the Brazilian Amazon: a mediating perspective and a mixed-method analysis. Population and Environment 34(1):86-112. http://dx.doi. org/10.1007/s11111-012-0173-5

Taylor, M. J., M. J. Moran-Taylor, and D. Rodman Ruiz. 2006. Land, ethnic, and gender change: transnational migration and its effects on Guatemalan lives and landscapes. Geoforum 37:41-61. http://dx.doi.org/10.1016/j.geoforum.2004.12.002 
Tschakert, P., O. T. Coomes, and C. Potvin. 2007. Indigenous livelihoods, slash-and-burn agriculture, and carbon stocks in Eastern Panama. Ecological Economics 60:807-820. http://dx.doi. org/10.1016/j.ecolecon.2006.02.001

Vanclay, J. K. 2003. Why model landscapes at the level of households and fields? Small-scale Forest Economics, Management and Policy 2(2):121-134.

Vergara, E. P., and J. R. Barton. 2013. Poverty and dependency in indigenous rural livelihoods: Mapuche experiences in the Andean foothills of Chile. Journal of Agrarian Change 13:234-262. http://dx.doi.org/10.1111/j.1471-0366.2012.00380.x

Vergara-Asenjo, G., D. Sharma, and C. Potvin. 2015. Engaging stakeholders: assessing accuracy of participatory mapping of land cover in Panama. Conservation Letters 0(0):1-8. http://dx. doi.org/10.1111/conl.12161

Wali, A. 1989. In eastern Panama, land is the key to survival. Cultural Survival Quarterly 13(3):3.

Wali, A. 1993. The transformation of a frontier-state and regional relationships in Panama, 1972-1990. Human Organization 52:115-129. http://dx.doi.org/10.17730/humo.52.2. $\underline{\mathrm{t} 7266 \mathrm{ng} 1131820 \mathrm{t} 2}$

Walker, R., E. Moran, and L. Anselin. 2000. Deforestation and cattle ranching in the Brazilian Amazon: external capital and household processes. World Development 28(4):683-699. http:// dx.doi.org/10.1016/s0305-750x(99)00149-7

Walker, R., S. Perz, M. Caldas, and L. G. T. Silva. 2002. Land use and land cover change in forest frontiers: the role of household life cycles. International Regional Science Review 25:169-199. http://dx.doi.org/10.1177/016001702762481230

Wickramasinghe, A. 2004. Gender and ecological sustainability: the tradition and wisdom of the local communities in a dry zone, Sri Lanka. Pages 171-192 in S. Krishna, editor. Livelihood and gender: equity in community resource management. SAGE Publications, New Delhi, India.

Wickstrom, S. 2003. The politics of development in indigenous Panama. Latin American Perspectives 30(4):43-68. http://dx.doi. org/10.1177/0094582x03030004006

World Bank. 2004. Sustaining forests: a development strategy. Washington, D.C., USA. http://dx.doi.org/10.1596/0-8213-5755-7

Xu, J., L. Lebel, and J. Sturgeon. 2009. Functional links between biodiversity, livelihoods, and culture in a Hani swidden landscape in southwest China. Ecology and Society 14(2):20. [online] URL: http://www.ecologyandsociety.org/vol14/iss2/art20/ 


\section{Appendix 1}

Supplementary information on methods used.

\section{Participatory methods}

The project objectives were conceived in collaboration with the village chief and the local three co-authors (MC, RBC and MBC). Each step of the research process entailed dialogue and consultation with these collaborators and key informants, and brainstorming sessions were held together prior to all data collection to decide upon culturally appropriate methods. At least one of these co-authors was present during each stage of data collection.

\section{Participatory mapping}

In 2013, a digitized version of the map was presented to interviewees and annotated for corrections. We held a focus group meeting with four key informants chosen by a traditional authority in which any further errors were addressed, and the map was re-digitized. Short fallow is cleared land (1-4 years old) used for agriculture, while tall fallow is fallow that is $\geq 5$ years old. After 2-3 years of cultivation, landowners clear a new hectare of land and leave the previous patch in fallow to regenerate. Secondary forest is considered land that has been un-cleared since settlement, but selective logging still occurs in both tall fallow and secondary forest. Parcels of land are rectangular and perpendicular to the highway, unlike the traditional land structure (Herlihy 1986), due to the nature of allotment at the time of settlement. A government engineer assigned each two-hundred metre stretch of land along the highway, from the highway to the northern border, to a single landowner.

\section{Participatory wealth ranking}

To quantify if there is a relationship between household wealth and land cover at the level of the individual parcel, we ranked each household in the community according to perceived wealth. To do this we held a focus group meeting in 2013 with two village authorities and three key informants to create a participatory wealth map of the community (following methods outlined in Geilfus 2002). A leading traditional authority chose these key informants based on their knowledge of the community's household level socio-economics. Focus group members decided to choose four levels of wealth from 1 (poorest) to 4 (wealthiest). Each household was colourcoded according to its perceived wealth, using whether the household owns land, livestock and household electronics; its relative income; and whether the house has walls, floors and a tin roof as proxies for wealth, as used by Tschakert et al. (2007) in neighbouring Ipetí-Emberá.

\section{Focus group discussion}

The leading traditional authority personally selected several of the female participants for the gender focus group based on their knowledge and participation in community congresses. The 
focus group was held in the communal house and was also open to any women who wished to join. Discussion centred on gendered divisions of labor and changes in divisions over time.

\section{Interviews}

We recorded all interviews for which consent to record was given (32 of 35). Ethics approval was obtained from the Instituto Nacional de Cultura (INAC) in Panama and the McGill Research Ethics Board. We used a purposive sampling strategy, selecting interviewees who were available and who fit into our target interview groups with the help of a leading traditional authority. Interviewees were categorized to ensure a range of generations and stakeholders in a future land use management plan was interviewed. We ensured that each wealth ranking was represented. Youth were characterised as $\leq 26$ years of age, unmarried and non-landowners. Landowners are those who were given their land to manage at the time of settlement, whereas land inheritors are the sons of these original settlers, who now own and manage their parental lands. While women can be landowners when the male household head has passed away and land has not been allotted to male inheritors, they are not generally the ones who manage the land in Piriatí (similar to traditional modes of inheritance, see Herlihy 1986, Kane 1986, 1994). Eight women were interviewed, to maintain roughly equal numbers of interviewees in each category. There was a geographical division between two parts of the community, drawn due to the asserted difference in worldviews between community members; the community leaders claim that those in "Site 1" are generally those who participate less in communal activities than those in "Site 2", who tend to have concrete houses (i.e. more wealth) and pasture, and who settled in the community after the first wave in the early 1970s. Thus we stratified the interviewees of the community a priori according to their location: 16 interviewees in "Site 1" and 15 in "Site 2". Four interviewees (3 landowners (one female) and 1 woman) live in Catrigandí. We chose to interview people in Catrigandí in order to capture any variation in perceived influences on land uses between community and non-community members. Approximately one third of all households in the village were surveyed (28 out of 88). We terminated sampling when novel information from interviews was saturated. These interviews were held in Spanish and Emberá and lasted from 30 minutes to 2 hours. The lead author (DS) led all interviews with the assistance and translation, as necessary, of the local co-authors (MC, RBC or MBC). All three local co-authors were present during the first interview, after which we held a discussion of appropriate questions and addressed any ambiguities, in order to refine the interviews (Table A1.1). 
Table A1.1. Examples of questions asked during semi-structured interviews.

\begin{tabular}{|c|c|}
\hline Subject & Questions \\
\hline \multirow[t]{5}{*}{ Origin } & Where are your parents from? \\
\hline & When did you come to Piriatí? Why? \\
\hline & How many people are in your family? \\
\hline & How many children are there in your family? \\
\hline & How old is the eldest person in your house? \\
\hline \multirow[t]{4}{*}{ Tenure history } & When did you obtain your land? \\
\hline & From whom did you obtain your land? \\
\hline & When did the previous owner receive the land? \\
\hline & How was the land when you obtained it? \\
\hline \multirow[t]{9}{*}{ Land uses } & When did you cut your forest? \\
\hline & When did you establish pasture? \\
\hline & How many cows do you have? \\
\hline & What type of pasture do you have? \\
\hline & Do you have a small-scale plantation? \\
\hline & $\begin{array}{l}\text { Was there a government programme or NGO that encouraged you to plant } \\
\text { a particular crop? }\end{array}$ \\
\hline & How much money did they give you? Did you like the project? \\
\hline & Do you share cows with another landowner? \\
\hline & $\begin{array}{l}\text { Can we reconstruct the history of the forest in your plot? How, when and } \\
\text { why has it changed? }\end{array}$ \\
\hline \multirow[t]{12}{*}{ Land management } & Why did you establish pasture? \\
\hline & Can you explain how you manage your land? Do you burn your land? \\
\hline & How many times per year? \\
\hline & For how long do you leave burned land in fallow? \\
\hline & Can you explain to me the burning cycle? \\
\hline & $\begin{array}{l}\text { Can you explain the rotation between fallow and cultivated land? Why do } \\
\text { you burn? }\end{array}$ \\
\hline & Do you produce for sale or self-consumption or both? \\
\hline & What do you plant? \\
\hline & Do you fell wood? \\
\hline & Do you rent out a part of your land? \\
\hline & Have you sold part of your land? \\
\hline & Do you have any problems with neighbours or colonist farmers? \\
\hline \multirow[t]{3}{*}{ Subsistence } & What do members of your family do? What do you do? \\
\hline & How many people in your family help with cultivation? \\
\hline & Do you receive social benefits? \\
\hline \multirow[t]{4}{*}{ Future land uses } & How do you want your lands to be in the future? \\
\hline & Do you want to see more pasture, more forest, more cultivated land? Why? \\
\hline & Where would you like to see more of this? Why? \\
\hline & Would you like to reforest your lands? Why? \\
\hline
\end{tabular}




\section{Literature Cited}

Geilfus, F. 2002. 80 herramientas para el desarrollo participativo: diagnóstico, planificación, monitoreo, evaluación. Instituto Interamericano de Cooperación para la Agricultura (IICA), San José, Costa Rica.

Herlihy, P.H. 1986. A Cultural Geography of the Embera and Wounan (Choco) Indians of Darien, Panama: With Emphasis on Recent Village Formation and Economic Diversification. Louisiana State University and Agricultural and Mechanical College, Louisana, USA.

Kane, S. 1986. Emberá (Chocó) village formation: The politics and magic of everyday life in the Darién forest. PhD dissertation, University of Texas at Austin.

Kane, S. 1994. The phantom gringo boat: Shamanic discourse and development in Panama. Smithsonian Institution, Washington D.C., USA.

Tschakert, P., O. T. Coomes, and C. Potvin. 2007. Indigenous livelihoods, slash-and-burn agriculture, and carbon stocks in Eastern Panama. Ecological Economics 60:807820. 


\section{Appendix 2}

Supplementary information on analysis of interviews.

All interviews for which audio recordings were made were transcribed verbatim in Microsoft Word. Preliminary codes related to factors that influence land uses were created from three interviews and used as a point of departure to code the remaining interviews during the first round of coding. The codes used were a combination of $a$ priori codes generated from background literature and a posteriori codes generated from the interview data themselves (Saldaña 2009). The first iteration of coding involved holistic coding, where sets of data were coded as a whole to be divided into more specific codes later, and in vivo coding, where direct quotes from the interview transcripts were used as codes (Fig. A2.1). An example of an in vivo code created is "no more strength" (used in the context of interviewees choosing not to clear forest for cultivation because of lack of energy to work the land). Codes were then grouped into broader categories derived from the research questions. For example, "no more strength" was put under the category of "reasons for having remaining forest" within the subcategory of "lack of resources". The second round of coding constituted pattern coding, where codes were grouped and renamed as more intangible explanatory codes (Saldaña 2009). For example, "no more strength" and the subcategory of "lack of resources" were then grouped with related codes under the more inclusive category of "availability of resources and labor" as a factor influencing land uses (i.e. it was pattern coded as "availability of resources and labor"). Each code was assigned to an inclusive category and new categories were created if there were codes that could not be subsumed under a pre-existing category. This process was repeated to ensure consistency. All coding was carried out on open source TAMS Analyzer software (version 4.45b7ahL).

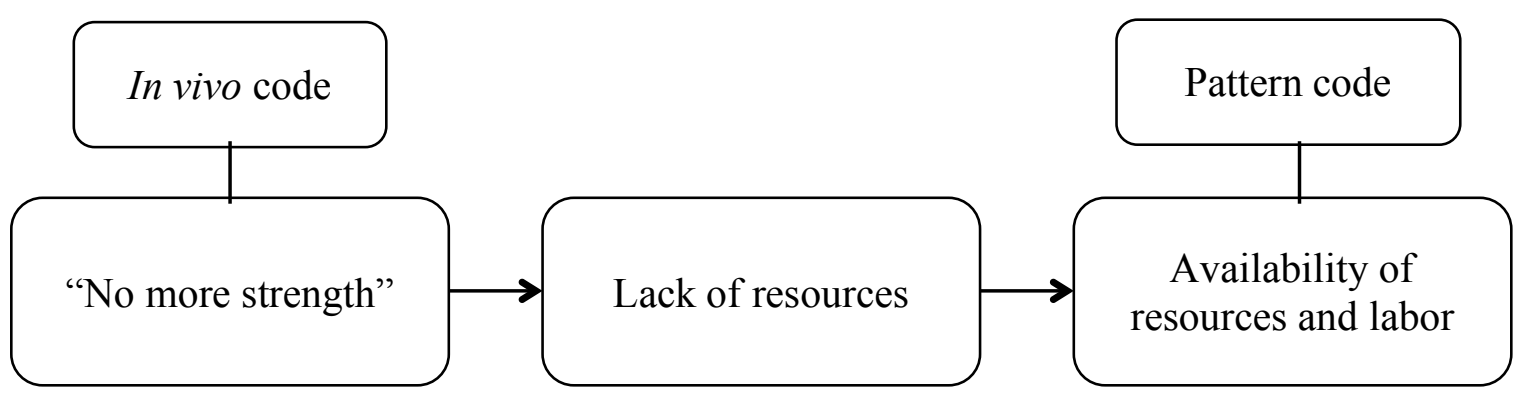

Fig. A2.1. Flow diagram illustrating an example of the process of first- and second-round coding to derive factors that influence the landscape. 
Canonical correspondence analyses (CCA; Borcard et al. 2011) were carried out to compare household-level land cover data as a dependent variable from the participatory map to the demographic characteristics of the interviewees, as well as to the social and ecological factors that emerged from interviews as influences on land uses. Three separate CCAs were carried out in RStudio (version 0.98.484): one for demographic characteristics; one for social factors influencing land uses; and one for ecological factors influencing land uses. Canonical correspondence analysis is a weighted redundancy analysis (RDA) that extends regression analysis to multivariate response data by combining multiple linear regression and principal component analysis (PCA) using a matrix of response variables and a matrix of explanatory variables (Borcard et al. 2011). The response matrix of the canonical correspondence analyses in this study consisted of the percent land cover values for each household for which data were available, and the explanatory matrices consisted of demographic characteristics and binary values of social and ecological influences on land uses (Table A2.1).

Only data from those interviewees for whom land cover data were available were used in the CCAs. All the interviewees with parcels to the north of the village had to be removed from the analysis due to the inability of the community members to accurately distinguish between the different parcels in this region. Therefore percent land cover values of these parcels could not be determined. This ambiguity was due to the large number of parcels in a small area and extensive cloud cover preventing referral to the satellite image of the area. Immigrants without land were excluded from analysis and those with land were grouped with landowners. Land inheritors were also grouped with landowners, since they manage their parcels. Youth and women were excluded from the demographic analysis, as they are not the ones who manage the parcels and determine land uses. Any interviewees for whom there were no demographic data for a particular category were removed from the analysis, due to the inability of CCA to manage empty cells. Thus, the interviewees living in Catrigandí, for whom wealth rankings were unavailable, were not included in the demographic CCA. As a result, all landowners with mapped parcels and complete demographic data were included in the demographic CCA $(n=10)$; while all interviewees with mapped parcels were included in the social CCA and in the ecological $\operatorname{CCA}(n=20)$.

Stepwise LDAs were not carried out as they did not make a significant difference to correlations.

Table A2.1. Possible inputs used for non-numerical variables in canonical correspondence analysis. 


\begin{tabular}{ll}
\hline Wealth ranking & 1 (poorest) -4 (wealthiest) \\
Location & 0 ("Site 1") or 1 ("Site 0") \\
Education & 0 (none) -13 (Bachelor's) \\
Place of origin & 0 (not Darién) or 1 (Darién) \\
Encroaching frontier settlement, e.g. & 0 (not mentioned) or 1 (mentioned) \\
\hline
\end{tabular}

\section{Literature Cited}

Borcard, D., F. Gillet, and P. Legendre. 2011. Numerical Ecology with R. Springer, New York, New York, USA.

Saldaña, J. 2012. The coding manual for qualitative researchers. SAGE Publications, Thousand Oaks, California, USA. 